\title{
Basal Cell Hyperplasia Observed at Biopsy Specimens after HIFU Therapy: Implication of Stemness for Organ Regeneration
}

\author{
Teiichiro Aoyagi*, Go Nagao, Isao Kuroda \\ Ibaraki Medical Center, Department of Urology, Tokyo Medical University, Ibaraki, Japan \\ Email: *aoyagite@tokyo-med.ac.jp
}

How to cite this paper: Aoyagi, T., Nagao, G. and Kuroda, I. (2020) Basal Cell Hyperplasia Observed at Biopsy Specimens after HIFU Therapy: Implication of Stemness for Organ Regeneration. Open Journal of Urology, 10, 35-41.

https://doi.org/10.4236/oju.2020.103005

Received: December 25, 2019

Accepted: January 28, 2020

Published: January 31, 2020

Copyright $\odot 2020$ by author(s) and Scientific Research Publishing Inc. This work is licensed under the Creative Commons Attribution International License (CC BY 4.0).

http://creativecommons.org/licenses/by/4.0/

\begin{abstract}
Prostatic basal cell is thought to play a pivotal role in hyperplastic change or carcinogenesis of prostate by their proliferation and stem cell transformation. We investigated stem cell transformation of basal cell hyperplasia observed at biopsy specimens after High Intensity Focused Ultrasound (HIFU) therapy for early stage prostate cancer. Patients and Methods: Basal cell hyperplasia was observed at biopsy specimens in two patients after HIFU therapy. Of these patients, one showed cancer recurrence. Specimens were studied with usual $\mathrm{HE}$, and immunohistochemical studies for prostate specific antigen (PSA), stem cell markers such as CD44, CD117 (c-kit), CD133 and Vimentin. Results: Both basal cell hyperplasia cases indicated PSA (-), CD44 (++), CD117 (-), Vimentin (-) and one specimen showed CD133 (++). Basal cell hyperplasia was presumed to appear during the regeneration process of normal prostate tissue after HIFU therapy, when basal cell proliferated and transformed to acinal cells through epithelial to mesenchymal transition.
\end{abstract}

\section{Keywords}

Prostate, Basal Cell Hyperplasia, HIFU, Epitelial to Mesenchymal Transition

\section{Introduction}

The prostate consists of three cell types. Basal cells are relatively undifferentiated, androgen-independent cells. Secretory luminal, and glandular cells are differentiated mature cells presenting androgen receptor and prostate specific antigen (PSA). The neuroendocrine cells are androgen-independent cells without presenting PSA [1]. Some basal cells are supposed to act as androgen-independent progenitor stem cells, and play an important role for initiating prostatic hyper- 
plasia and/or cancer formation [2]. Stemness refers to the properties that cells have a potential to self-renewal, multi-lineage differentiation and proliferation [3]. Stem cells have two types, embryonic type from early division of fertilized egg, and somatic type from developed tissues and organs. Each organ has somatic type stem cells preparing for repair of tissue injury, usually residing in specialized microenvironment or niches. Basal cell hyperplasia $(\mathrm{BCH})$ is observed in association with a repairing process of tissue damage such as inflammation or injury [4]. Basal cell hyperplasia also has a relation to prostate carcinogenesis [5]. Histopathological findings after high-intensity focused ultrasound (HIFU) therapy mainly composed of coagulation necrosis and granulomatous inflammation. Biermann et al. reported that basal cell hyperplasia was observed in $68 \%$ of benign prostate after treated by HIFU [6]. Here we report two $\mathrm{BCH}$ in biopsy specimens observed after HIFU therapy for early stage prostate cancer, and discuss the meaning of them by immunohistochemical studies.

\section{Cases Presentation}

Case 1. Sixty five year-old man presenting Gleason $4+3$ adenocarcinoma on 4 out of 12 biopsy site, initial PSA was $5.87 \mathrm{ng} / \mathrm{ml}$. He had HIFU with short-term Degarelix therapy, that is, adding LH-RH antagonist (Degarelix) twice between HIFU therapy [7], as T1cN0M0 early stage prostate cancer. Nadir PSA was 0.024 $\mathrm{ng} / \mathrm{ml}$ at 9 months after the therapy, however it suddenly rose $1.653 \mathrm{ng} / \mathrm{ml}$ at 12 months. Re-biopsy indicated no cancer relapse from six biopsy specimens, and also showed $\mathrm{BCH}$ on one specimen. The patient's PSA gradually decreased spontaneously without any therapy, keeping as low as $0.371 \mathrm{ng} / \mathrm{ml}$ after three years.

Case 2. Sixty eight year-old man presenting Gleason $3+4$ adenocarcinoma on 2 out of 10 biopsy site, initial PSA was $6.09 \mathrm{ng} / \mathrm{ml}$. He underwent HIFU therapy as T1cN0M0 early stage prostate cancer. Nadir PSA after the therapy was 3.45 $\mathrm{ng} / \mathrm{ml}$, and re-biopsy after 1 year from HIFU at PSA $6.03 \mathrm{ng} / \mathrm{ml}$, indicated Gleason $4+3$ adenocarcinoma on 2 out of 6 biopsy site. $\mathrm{BCH}$ was observed one of the re-biopsy specimen. The patient underwent second HIFU adding short-term Degarelix this time [7]. After the second HIFU therapy, he showed no relapse with PSA $0.365 \mathrm{ng} / \mathrm{ml}$ at 5 years.

\section{Immunohistochemical Staining and Results}

Cancer and $\mathrm{BCH}$ histological specimens of both cases were examined the stemness comparing the normal tissue. Hematoxylin and Eosin (HE), PSA, prostatic stem cell marker [8] such as CD44 (Gene Tex Hsinchu, Taiwan), CD117 (c-kit) (abcam Cambridge, England), Vimentin (Santa cruz Dallas, USA), CD133 (ENOGENE NY, USA) were immunohistochemically stained following previously reported method [7]. Both patients accepted on the study and report by signature and the study was approved the hospital's IRB committee (Institutional Review Board of Tokyo Medical University, Ibaraki Medical Center, approved 
2013.6). The stained results were indicated in Table 1. Normal gland and cancer tissues showed positive PSA and negative for all stem cell markers (Figure 1). Both BCH showed PSA negative (Figure 2(b), Figure 3(b)), CD 133 positive in case 1 (Figure 2(c), Figure 3(c)), CD117 negative, Vimentin negative, and CD44 strongly positive (Figure 2(d), Figure 3(d)). Vimentin was stained only in interstitial cells for normal tissue.

\section{Discussion}

Only a few reports have observed on the histological findings after HIFU therapy. Especially histological reports after a long period from HIFU are very few [8] [9]. $\mathrm{BCH}$ was reported to be seen among the usual findings after HIFU therapy such as vast coagulation necrosis, fibrosis and inflammation [6]. Stem cells are reported to be engaged by bi-directional action according to microenvironment [10]. Vast and strong tissue damage induced by HIFU might activate stem cells residing in environmental niche. Although the exact mechanism of forming

Table 1. Histological findings of biopsy specimens.

\begin{tabular}{cccccccc}
\hline case & specimen & H \& E & PSA & CD44 & CD133 & c-kit & vimentin \\
\hline 1,2 & Pre-HIFU & cancer & + & - & - & - & - \\
& & normal & + & - & - & - & Int. cell \\
1 & Post-HIFU & BCH & - & ++ & ++ & - & - \\
2 & Post-HIFU & BCH & - & ++ & - & - & - \\
\hline
\end{tabular}

Post HIFU specimens were obtained after 1 year of HIFU therapy respectively.

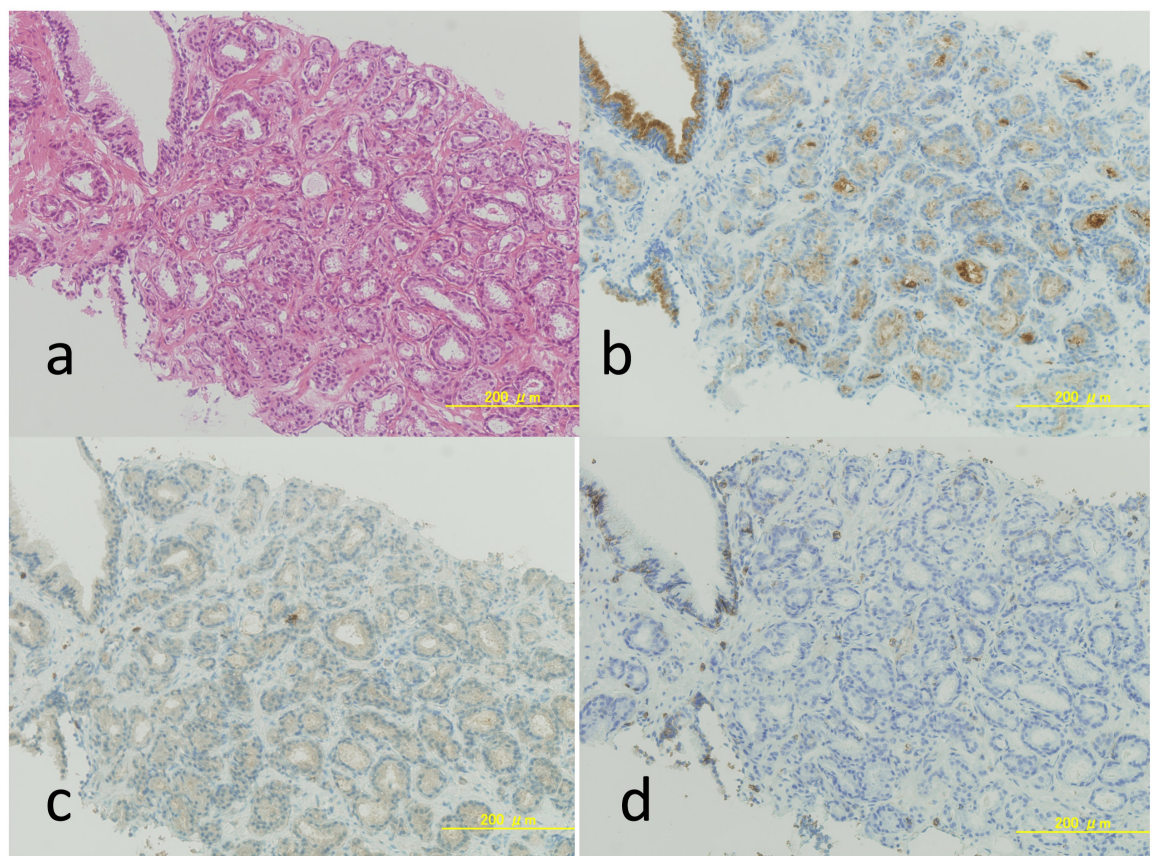

Figure 1. Pre-HIFU biopsy findings of case 1. (a) H \& E Gleason $4+3$ adenocarcinoma, reduced from 40×, (b) PSA weakly positive 40×, (c) CD133 negative 40×, (d) CD44 negative $40 \times$. 


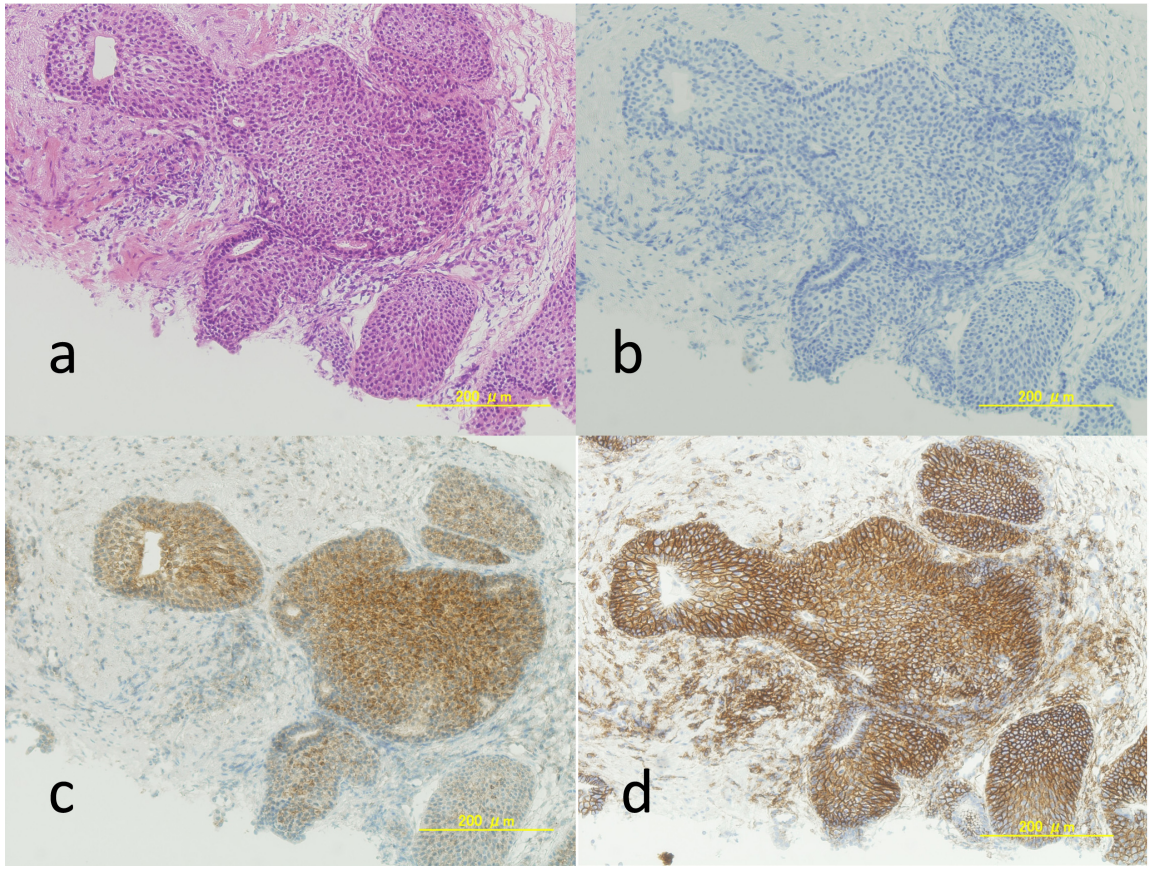

Figure 2. One year, post-HIFU biopsy findings of case 1, (a) H \& E Basal cell hyperplasia, reduced from 10×, (b) PSA negative 10×, (c) CD133 positive 10×, (d) CD44 positive 10×.

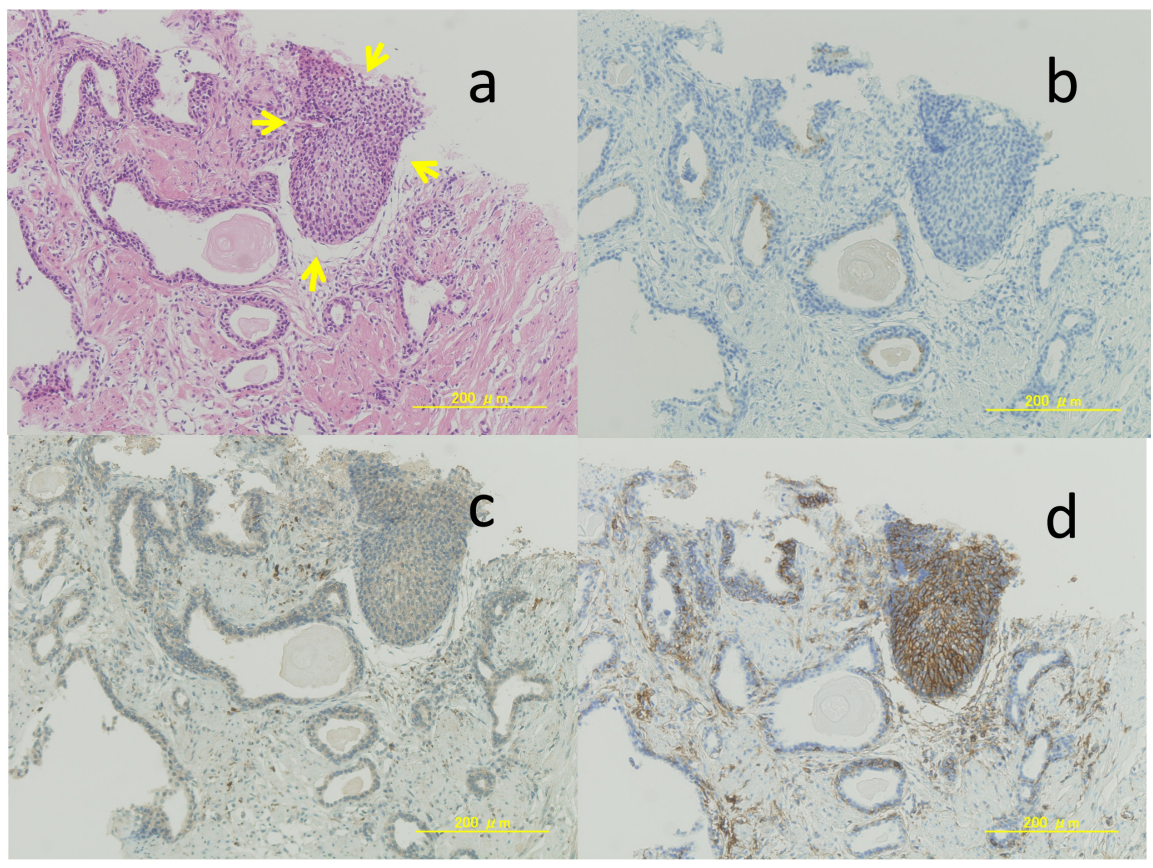

Figure 3. One year, post-HIFU biopsy findings of case 2, (a) H \& E basal cell hyperplasia

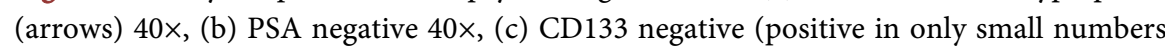
of interstitial cells) $40 \times$, (d) CD44 positive $40 \times$.

$\mathrm{BCH}$ was unclear, the proliferation of basal cell differentiated stem cells may trigger the initiation of cancer or hyperplastic formation [11] [12] [13]. The apoptosis of luminal cells is also reported as a trigger of proliferation induced by inflammation or change of hormonal environment [14]. The stemness property 
of these basal cells is thought to be very important for tissue regeneration [15].

After HIFU therapy, all prostatic tissues including cancer become necrosis, and consequently change to fibrotic tissue. Small amount of survived basal cells are assumed to be a stem cell for tissue regeneration. It is probable that $\mathrm{BCH}$ is grown from one of these proliferated basal cells showing stemness. Usually basal cells produce $\mathrm{CD} 44$, and CD44 are reported to play an important role for cells indicating stemness [16]. Various kinds of cells turned to positive for CD44 by epithelial to mesenchymal transition. Prostate cancer cells are reported that expression of CD44 and/or CD133 contributed to acquisition of hormone refractoriness and metastasis [17] [18] [19]. Wei et al. reported that expression of CD133 might indicate some proliferation activity in prostatic cells [20]. Interestingly, in our case, one showed strongly positive for CD133, and the others did not. Case $1 \mathrm{BCH}$ might be a new proliferating hyperplasia. $\mathrm{BCH}$ is presumed the consequence of stem cell transformation of basal cell, and $\mathrm{BCH}$ represents the possibility of development of benign prostatic hyperplasia and/or cancer in the somewhere of background [11] [16].

\section{Conclusion}

Stem cell transformation of $\mathrm{BCH}$ was observed at biopsy specimens after HIFU therapy for two early stage prostate cancer patients. $\mathrm{BCH}$ is presumed to represent regeneration of prostatic tissue, and also this "stemness of basal cell" might induce benign hyperplastic change and/or malignant transformation in the future.

\section{Conflicts of Interest}

The authors declare no conflicts of interest regarding the publication of this paper.

\section{References}

[1] Cunha, G.R., Vezina, C.M., Isaacson, D., Ricke, W.A., et al. (2018) Development of the Human Prostate. Differentiation, 103, 24-45.

https://doi.org/10.1016/j.diff.2018.08.005

[2] Carvalho, H.F., Taboga, S.R., Felisbino, S.L. and Biancardi, M.F. (2017) Prostate Epithelium Basement Membrane and Prostate Cell Biology: 20 Years. Cell Biology International, 41, 1170-1173. https://doi.org/10.1002/cbin.10831

[3] Lathia, J. and Liu, H. (2017) Overview of Cancer Stem Cells and Stemness for Community Oncologists. Targeted Oncology, 12, 387-399.

https://doi.org/10.1007/s11523-017-0508-3

[4] Henry, G., Malewska, A., Mauck, R., Gahan, J., et al. (2017) Molecular Pathogenesis of Human Prostate Basal Cell Hyperplasia. Prostate, 77, 1344-1355. https://doi.org/10.1002/pros.23394

[5] Montiloni, R., Mazzucchelli, R., Stramazzotti, D., Scarpelli, M., Beltran, A.L. and Bostwick, D.G. (2005) Basal Cell Hyperplasia and Basal Cell Carcinoma of the Prostate: A Comprehensive Review and Discussion of a Case with c-erbB-2 Expression. Journal of Clinical Pathology, 58, 290-296. 
https://doi.org/10.1136/jcp.2004.019596

[6] Biermann, K., Montironi, R., Lopez-Beltran, A., Zhang, S. and Cheng, L. (2010) Histopathological Findings after Treatment of Prostate Cancer Using High-Intensity Focused Ultrasound (HIFU). The Prostate, 70, 1196-1200. https://doi.org/10.1002/pros.21154

[7] Aoyagi, T. and Kuroda, I. (2016) Enhancement of HIFU Effect by Simultaneous Short Course Degarelix for Early Stage Prostate Cancer: A Pilot Study. Open Journal of Urology, 6, 49-54. https://doi.org/10.4236/oju.2016.63010

[8] Van Leenders, G.J.L.H., Beerlage, H.P., Ruijter, E.T., de la Rosette, J.J.M.C.H. and van de Kaa, C.A. (2000) Histopathological Changes Associated with High Intensity Focused Ultrasound (HIFU) Treatment for Localized Adenocarcinoma of the Prostate. Journal of Clinical Pathology, 53, 391-394. https://doi.org/10.1136/jcp.53.5.391

[9] Ryan, P., Finelli, A., Lawrentschuk, N., Fleshner, N., et al. (2012) Prostatic Needle Biopsies Following Primary High Intensity Focused Ultrasound (HIFU) Therapy for Prostatic Adenocarcinoma: Histopathological Features in Tumor and Non-Tumor Tissue. Journal of Clinical Pathology, 65, 729-734. https://doi.org/10.1136/jclinpath-2011-200460

[10] Aponte, P.M. and Caicedo, A. (2017) Stemness in Cancer: Stem Cells, Cancer Stem Cells, and Their Microenvironment. Stem Cells International, 2017, Article ID: 5619472. https://doi.org/10.1155/2017/5619472

[11] Prajapati, A., Gupta, S., Mistry, B. and Gupta, S. (2013) Prostate Stem Cells in the Development of Benign Prostate Hyperplasia and Prostate Cancer: Emerging Role and Concepts. BioMed Research International, 2013, Article ID: 107954. https://doi.org/10.1155/2013/107954

[12] Ferrucci, D., Biancardi, M.F., Nishan, U., Rosa-Ribeiro, R. and Carvalho, H.F. (2017) Desquamation Takes Center Stage at the Origin of Proliferative Inflammatory Atrophy, Epithelial-Mesenchymal Transition, and Stromal Growth in Benign Prostate Hyperplasia. Cell Biology International, 41, 1265-1270. https://doi.org/10.1002/cbin.10867

[13] Kwon, O.J., Zhang, B., Zhang, L. and Xin, L. (2016) High Fat Diet Promotes Prostatic Basal-to Luminal Differentiation and Accelerates Initiation of Prostate Epithelial Hyperplasia Originated from Basal Cell. Stem Cell Research, 16, 682-691. https://doi.org/10.1016/j.scr.2016.04.009

[14] Aoyagi, T., Takizawa, I. and Kuroda, I. (2018) Basal Cell Proliferation Induced by Chlormadinone Acetate Suggests Stem Cell Transformation of Prostatic Cells. Journal of Cancer Therapy, 9, 268-273. https://doi.org/10.4236/jct.2018.93024

[15] Toivanen, R., Mohan, A. and Dhen, M.M. (2016) Basal Progenitors Contribute to Repair of the Prostate Epithelium Following Induced Luminal Anoikis. Stem Cell Reports, 6, 660-667. https://doi.org/10.1016/j.stemcr.2016.03.007

[16] Xu, H., Tian, Y., Wu, H., Liu, Q., et al. (2015) The Role of CD44 in Epithielial-Mesenchymal Transition and Cancer Development. OncoTargets and Therapy, 8, 3783-3792. https://doi.org/10.2147/OTT.S95470

[17] Shang, Z., Cai, Q., Zhang, M., Zhu, S., et al. (2014) A Swich from CD44+ Cell to EMT Cell Drives the Metastasis of Prostate Cancer. Oncotarget, 6, 1202-1216. https://doi.org/10.18632/oncotarget.2841

[18] Shi, X., Gipp, J., Dries, M. and Bushman, W. (2014) Prostate Progenitor Cells Proliferate in Response to Castration. Stem Cell Research, 13, 154-163. https://doi.org/10.1016/j.scr.2014.04.005

[19] Moltzahn, F. and Thalmann, G.N. (2013) Cancer Stem Cells in Prostate Cancer. 
Translational Andrology and Urology, 2, 242-253.

[20] Wei, X., Orjalo, A.V. and Xin, L. (2016) CD133 Does Not Enrich for the Stem Cell Activity in Vivo in Adult Mouse Prostates. Stem Cell Research, 16, 597-606. https://doi.org/10.1016/j.scr.2016.03.003 